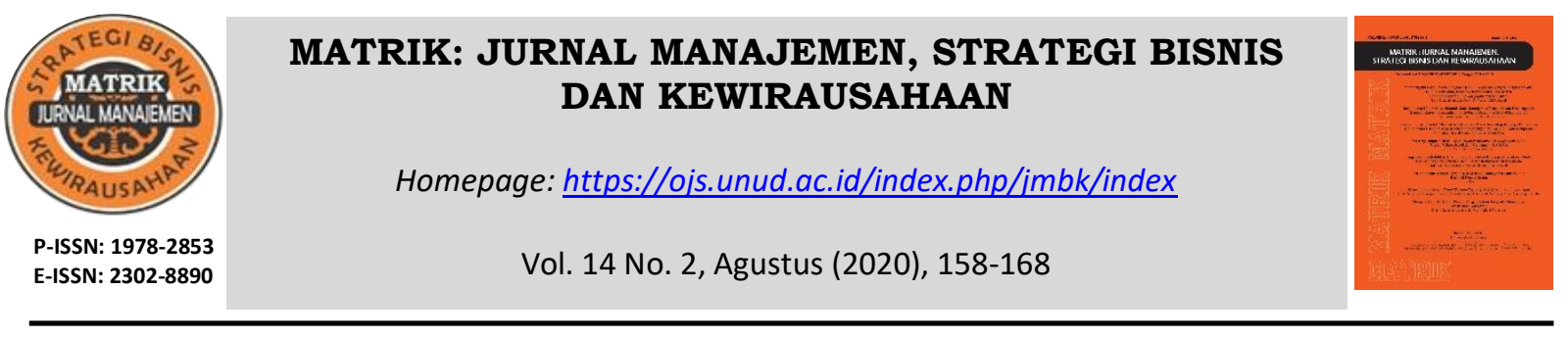

\title{
Pengujian Anomali Size Effect Di Pasar Modal Indonesia
}

\author{
Luh Gede Sri Artini' ${ }^{1)}$, Ni Putu Ayu Darmayanti ${ }^{2)}$, Gede Merta \\ Sudiartha ${ }^{3)}$ \\ ${ }_{1,2,3}$ Fakultas Ekonomi dan Bisnis Universitas Udayana \\ email: lg_artini@yahoo.com
}

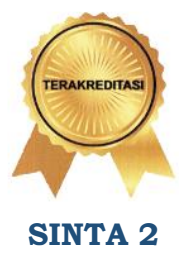

DOI : https://doi.org/10.24843/MATRIK:JMBK.2020.v14.i02.p03

\begin{abstract}
ABSTRAK
Penelitian anomali size effect di Pasar Modal Indonesia ini bertujuan untuk membuktikan pengaruh ukuran perusahaan terhadap kinerja portofolio saham. Metode analisis statistik deskriptif digunakan untuk menjelaskan sebaran data dan uji beda dua rata-rata independen untuk membandingkan kinerja portofolio saham dengan indeks Sharpe dari portofolio saham ukuran besar dengan portofolio saham ukuran kecil yang telah dibentuk dari sahamsaham yang konsisten masuk ke dalam Indeks Kompas 100 periode 2012-2017. Hasil penelitian menunjukkan indeks Sharpe portofolio saham ukuran besar lebih baik daripada portofolio saham ukuran kecil. Hasil uji beda menunjukkan perbedaan rata-rata tersebut tidak signifikan, sehingga dapat disimpulkan anomali size effect tidak terjadi di Pasar Modal Indonesia khususnya pada saham-saham yang terdaftar di Indeks Kompas 100.
\end{abstract}

Kata kunci: anomali size effect, portofolio saham ukuran besar-kecil, indeks sharpe

\section{The Measurement of Size Effect Anomaly in Indonesian Capital Market}

\begin{abstract}
The research on the size effect anomaly in the Indonesian Capital Market aims to find out the effect of company size on the performance of the stock portfolio. Descriptive statistical analysis method is used to explain the distribution of data and independent sample tests to compare the performance of stock portfolios of Sharpe index of large-size stock portfolios and small size stock portfolios formed from stocks that is consistently included in the Compass Index 100 during 2012-2017. The results of the study show that the Sharpe index of large-size stock portfolios is better than the small-size stock portfolio. The results of different tests show that the mean difference is not significant, so it can be concluded that the anomaly size effect does not occur in the Indonesian Capital Market, especially in stocks listed on the Kompas 100 Index.
\end{abstract}

Keyword: size effect anomaly, large-small sized stock portfolio, sharpe index

\section{PENDAHULUAN}

Saham merupakan sekuritas yang paling diminati investor di pasar modal karena keunggulan saham yang mampu memberikan imbal hasil yang besar dalam jangka waktu yang relatif singkat. Pengembalian saham dapat berupa dividen dan capital gain, pengembalian saham kompetitif dengan instrumen investasi lainnya namun risiko yang dihadapi juga lebih tinggi dibanding instrumen investasi lainnya (Ardiana, 2016: 23). 
Keuntungan yang tinggi dengan risiko yang tinggi bisa diatasi oleh investor dengan melakukan portofolio pada saham. Terdapat dua strategi portofolio, yaitu strategi aktif dan strategi pasif. Strategi pasif menggambarkan tindakan investor yang cenderung pasif dalam mencari informasi untuk mendapatkan return yang lebih tinggi (Jones, 2014: 300). Strategi aktif menggambarkan tindakan investor yang aktif mencari informasi-informasi untuk memperoleh return yang lebih tinggi. Investor dapat menggunakan pendekatan fundamental dengan memanfaatkan data seperti earning, dividen, penjualan, dan lainnya dalam melakukan strategi aktif. Investor juga dapat menggunakan pendekatan teknikal dengan mencari pola pergerakan saham yang bisa digunakan periode selanjutnya (Jones, 2014: 304). Informasiinformasi yang diperoleh investor akan mempengaruhi harga saham di pasar modal dan akan berpengaruh pada return saham yang diperoleh investor.

Informasi-informasi yang diserap pada pasar modal akan membentuk harga keseimbangan baru sebagai respon pasar terhadap informasi, harga saham yang diperdagangkan telah mencerminkan semua informasi, baik informasi masa lalu, informasi saat ini, dan juga informasi di masa depan tanpa adanya lag. Konsep ini dikenal dengan konsep pasar modal efisien (Hartono, 2017: 605). Konsep pasar modal efisien menyatakan bahwa ketika terdapat ketidaksesuaian harga saham maka hal itu merupakan bentuk dari ketidaksempurnaan penyerapan informasi. Ketidaksesuaian harga merupakan bentuk dari tidak efisiennya pasar yang berdampak pada semakin banyaknya kesempatan untuk mendapatkan return yang abnormal, yaitu dengan menerapkan berbagai strategi pemilihan saham dalam pembentukan portofolio berdasarkan semua informasi ketidaksesuaian harga.

Penelitian terdahulu telah membuktikan adanya ketidaksesuaian harga. Beberapa diantaranya berkaitan dengan ukuran perusahaan atau size effect oleh (Banz, 1981) dan price earning ratio oleh (Basu, 1977). Ketidaksesuaian harga ini kemudian disebut dengan anomali di dalam pasar yang efisien, karena dalam pasar efisien tidak ada investor yang mampu memperoleh abnormal return dengan memanfaatkan informasi yang ada.

Anomali size effect merupakan anomali yang sangat dominan hampir di seluruh pasar modal (Yanuarta, 2012), fenomena ini telah didukung oleh beberapa penelitian terdahulu diantaranya di India penelitian Sobti (2018), Washer et al. (2016), Balakrishnan dan Maiti (2015), Pandey dan Sehgal (2015), Sehgal dan Balakrishnan (2013), di Afrika Selatan Boamah dan Nicholas (2015), di Pakistan oleh Iqram ul Haq (2014), di Turki Eraslan (2013), di Inggris Hwang et al. (2013), di Amerika Serikat Simlai (2009), di New Zeland Nartea et al. (2009), dan di China Rutledge et al. (2008).

Anomali size effect yang dikenal juga dengan istilah small firm effect, menggambarkan fenomena bahwa perusahaan-perusahaan kecil memberikan return yang lebih tinggi dibandingkan perusahaan besar (Banz, 1981). Berdasarkan fenomena tersebut, maka strategi pemilihan portofolio berdasarkan size effect ini akan memberikan return yang outperform (Yanuarta, 2012).

Penelitian terkait anomali size effect sudah pernah dilakukan di Pasar Modal Indonesia. Penelitian yang dilakukan Yanuarta (2012) menunjukkan hasil bahwa anomali size effect tidak terjadi di Pasar Modal Indonesia. Penelitian yang dilakukan oleh Yani (2014) yang mengaitkan anomali size effect dengan January effect menemukan bahwa tidak terjadi anomali size effect. 
Di Pasar Modal Indonesia penelitian Mikhael dan Widanaputra (2018) yang juga mengaitkan anomali size effect dengan January effect juga menunjukkan hasil yang sama dengan penelitian Yani. Penelitian Kurniawan dan Pubawangsa (2018) juga menunjukkan tidak adanya anomali size effect. Berbeda dengan penelitian lainnya, penelitian Octavio dan Lantara (2014) menunjukkan adanya anomali size effect pada portofolio saham loser dalam pengujian market overaction. Penelitian Dewi dan Sri Artini (2014) yang menguji efisien pasar menunjukkan bahwa Pasar Modal Indonesia tidak efisien. Tidak terbuktinya efisiensi Pasar Modal Indonesia mengindikasikan kemungkinan adanya anomali yang terjadi.

Penelitian ini bertujuan untuk menganalisis serta menguji kinerja portofolio saham ukuran besar dibandingkan dengan portofolio saham ukuran kecil sehingga melalui penelitian ini akan membuktikan ada atau tidaknya anomali size effect di Pasar Modal Indonesia. Penelitian ini menggunakan saham yang termasuk ke dalam Indeks Kompas 100 sebagai ruang lingkup penelitian. Alasan penggunaan Indeks Kompas 100 karena memiliki likuiditas tinggi, yang berimplikasi pada penyebaran informasi yang luas dan tidak ada yang dapat mengendalikan harga di pasar, sehingga harga yang terjadi diasumsikan sudah mendekati harga sebenarnya. Indeks Kompas 100 mampu mewakili hingga 70 persen - 80 persen kapitalisasipasar di Pasar Modal Indonesia, selain itu jenis saham dari berbagai sektor juga masuk ke dalam Indeks Kompas 100, sehingga Indeks Kompas 100 mampu mewakili kondisi Pasar Modal Indonesia (Dwipayana dan Wiksuana, 2017).

Hasil penelitian diharapkan dapat memberikan bukti empiris mengenai pengujian anomaly size effect di pasar modal Indonesia sertra memberikan masukan bagi investor di Pasar Modal Indonesia

Investasi adalah penundaan konsumsi periode sekarang untuk dimasukkan ke aktiva produktif selama periode waktu tertentu (Hartono, 2017:5). Salah satu aktivitas investasi adalah kegiatan investasi pada aset finansial. Aset finansial adalah klaim berbentuk surat berharga atas sejumlah aset-aset pihak penerbit surat berharga tersebut.

Investor yang berinvestasi memiliki dasar keputusan yang terdiri dari return, risiko, serta hubungan antara return dan risiko. Return merupakan tingkat keuntungan investasi. Manajemen investasi mengenal dua istilah return, yaitu return harapan dan return aktual. Return harapan merupakan tingkat return yang diantisipasi investor di masa datang. Sedangkan return aktual merupakan tingkat return yang telah diperoleh investor pada masa lalu. Risiko adalah kemungkinan realisasi return aktual lebih rendah dari return minimum yang diharapkan. Sikap investor terhadap risiko akan sangat tergantung kepada preferensi investor tersebut terhadap risiko. Investor yang lebih berani akan memilih risiko investasi yang lebih tinggi, diikuti oleh return harapan yang tinggi pula dan sebaliknya (Jones, 2014: 8).

Hubungan risiko dan return harapan dari suatu investasi merupakan hubungan yang searah dan linear. Hubungan ini memiliki arti, semakin besar return harapan, semakin besar pula tingkat risiko yang perlu dipertimbangkan. Kondisi tersebut yang mengakibatkan tidak semua investor berani menginvestasikan dananya pada aset yang menawarkan return tinggi karena juga mengandung risiko yang tinggi. Berdasarkan karakteristik antara return dan risiko tersebut maka investor sering membentuk portofolio untuk meminimalkan risiko atau kerugian yang dihadapi dari investasi yang dilakukan (Jones, 2014:9). 
Ketika melakukan investasi terdapat proses keputusan investasi yang terdiri dari lima tahap keputusan yang berjalan terus-menerus sampai tercapai keputusan investasi yang terbaik (Tandelilin, 2010:12). Tahap-tahap keputusan investasi tersebut meliputi: (1) Penentuan tujuan investasi. (2) Penentuan kebijakan investasi, tahap ini dimulai dengan penentuan keputusan alokasi aset. (3) Pemilihan strategi portofolio, dengan menggunakan strategi aktif atau pasif. Strategi portofolio pasif merupakan strategi dimana investor cenderung pasif dalam melakukan portofolio. Strategi portofolio aktif pada dasarnya meliputi tindakan investor yang secara aktif melakukan pemilihan dan jual beli saham, mencari informasi, mengikuti waktu, dan pergerakan harga saham, serta berbagai tindakan aktif lainnya untuk menghasilkan abnormal return. (4) Pemilihan aset, dimana pada tahap ini diperlukan pengevaluasian setiap sekuritas yang ingin dimasukkan dalam portofolio sehingga menggahasilkan portofolio yang efisien.(5) Pengukuran dan evaluasi kinerja portofolio, terkait dengan dua isu utama yaitu mengevaluasi apakah return portofolio yang telah dibentuk pada periode formasi mampu memberikan return yang lebih besar dibandingkan return portofolio lainnya yang dijadikan sebagai patokan dan mengevaluasi apakah return yang diperoleh sudah sesuai dengan tingkat risiko yang harus ditanggung. Ketika melakukan penilaian kinerja portofolio memerlukan variabel-variabel yang relevan. Variabel tersebut adalah tingkat keuntungan dan risiko portofolio saham.

Pengukuran kinerja investasi yang diawali oleh Markowitz telah direduksi menjadi sebuah parameter atau ukuran tersebut dikaitkan dengan risiko, baik risiko total maupun risiko sistematis. Konsep ini didasarkan pada gabungan antara return dan risiko (risk-adjusted return) (Hartono, 2017:725). Beberapa ukuran kinerja portofolio yang menggabungkan antara return dan risiko adalah indeks Sharpe, indeks Treynor, dan indeks Jensen.

Indeks Sharpe dikembangkan oleh William Sharpe, yang mendasarkan pertimbangannya pada konsep garis pasar modal sebagai patokan, yaitu dengan cara membagi premi risiko portofolio dengan standar deviasinya. Premi risiko adalah perbedaan atau selisih antara rata-rata kinerja yang dihasilkan oleh portofolio dengan rata-rata kinerja investasi yang bebas risiko. Standar deviasi merupakan risiko fluktuasi portofolio yang dihasilkan karena berubah-ubahnya return yang dihasilkan dari sub-periode ke sub-periode lainnya selama seluruh periode. Semakin tinggi indeks Sharpe suatu portofolio dibanding portofolio lainnya, maka semakin baik kinerja portofolio tersebut. lndeks Treynor merupakan ukuran kinerja portofolio yang dikembangkan oleh Jack Treynor. Indeks Treynor melihat kinerja portofolio dengan cara menghubungkan tingkat return portofolio dengan besarnya risiko dari portofolio tersebut. Indeks Treynor menggunakan garis pasar sekuritas sebagai patokan. Asumsi yang digunakan oleh Treynor adalah portofolio sudah terdiversifikasi dengan baik sehingga risiko yang dianggap relevan adalah risiko sistematis (diukur dengan beta). Semakin tinggi indeks Treynor yang dimiliki sebuah portofolio, berarti kinerja portofolio tersebut akan menjadi relatif lebih baik dibandingkan portofolio yang mempunyai indeks Treynor yang lebih rendah. lndeks Jensen merupakan indeks yang menunjukkan perbedaan antara tingkat return aktual yang diperoleh portofolio dengan tingkat return yang diharapkan jika portofolio tersebut berada pada garis pasar modal. Indeks Jensen yang positif akan memperlihatkan kinerja superior, sebaliknya indeks Jensen yang negatif akan memperlihatkan kinerja lebih rendah dari return pasar (Hartono, 2017:726). 
Pasar modal efisien adalah pasar dimana harga sekuritas yang diperdagangkan bergerak dengan cepat sebagai respon dari adanya informasi baru, sehingga harga sekuritas tersebut mampu mencerminkan semua informasi yang tersedia mengenai perusahaan (Hartono, 2017:605). Pasar efisien diklasifikasikan ke dalam efficient market hypoteis, yaitu (1) Pasar efisien dalam bentuk lemah (weak form) berarti harga sekuritas akan menggambarkan semua informasi masa lalu atau historis seperti informasi mengenai harga dan volume perdagangan yang terjadi di masa lalu. (2) Pasar efisien dalam bentuk setengah kuat (semi strong form) berarti harga sekuritas akan menggambarkan semua informasi masa lalu dan juga informasi yang dipublikasikan saat ini seperti dividen, pengumuman stock split, penerbitan saham baru, kesulitan keuangan perusahaan, dan sebagainya. (3) Pasar efisien dalam bentuk kuat (strong form) berarti harga sekuritas akan menggambarkan semua informasi masa lalu, informasi yang dipublikasikan saat ini, dan informasi yang tidak terpublikasi (Hartono, 2017,606).

Ketika adanya ketidaksesuaian harga maka hal itu merupakan bentuk dari ketidaksempurnaan penyerapan informasi. Hipotesis pasar efisien menyatakan, ketidaksesuaian harga merupakan bentuk dari tidak efisiennya pasar yang berdampak pada semakin banyaknya kesempatan untuk mendapatkan return yang abnormal, yaitu dengan menerapkan berbagai strategi pemilihan saham berdasarkan semua informasi ketidaksesuaian harga tersebut. Kondisi tersebut kemudian dikenal dengan istilah anomali pasar (Hartono, 2017:667).

Anomali secara umum berarti penyimpangan yang terjadi dari model keseimbangan yang ada. Model keseimbangan menyatakan, return sebuah saham akan sebanding dengan risiko yang melekat pada saham itu. Return saham akan berubah jika premi risiko atau sensitifitasnya berubah juga. Jika tidak ada perubahan maka tidak akan terjadi perubahan dengan harga saham perusahaan (return). Fenomena ini berkaitan dengan penyimpangan dari model keseimbangan Capital Asset Pricing Model (CAPM). CAPM menjelaskan, sensitifitas sebuah saham diukur terhadap pasar, sehingga keluarlah konsep beta saham. Nilai beta (sensitifitas) yang tinggi menggambarkan risiko yang lebih tinggi juga. Apabila beta dalam CAPM tidak bisa menjelaskan perbedaan return sebuah saham maka itulah keadaan dimana terjadinya anomali (Hartono, 2017:667).

Salah satu jenis anomali yaitu anomali size effect, dimana anomali ini merupakan hasil dari pengujian adanya abnormal return yang terkait dengan karakteristik perusahaan. Anomali size effect merupakan anomali yang sudah terbukti secara universal pada beberapa penelitian di luar negeri (Sobti 2018 Washer et al., 2016; Balakrishnan and Maiti 2015; Pandey and Sehgal 2015; Sehgal and Balakrishnan 2013 di India, Boamah 2015 di Afrika Selatan, Iqram ul Haq and Kashif Rashid 2014 di Pakistan, Eraslan 2013 di Turki, Hwang et al., 2013 di Inggris, di India, Nartea et al, 2009 di New Zeland, Simlai 2009 di Amerika Serikat, Rutledge et al.,2008 di China).

Anomali size effect pertama kali ditemukan oleh Banz tahun 1981 di pasar modal Amerika. Banz menemukan bahwa terjadi hubungan terbalik (negatif) antara ukuran perusahaan dengan return saham. Artinya, saham-saham perusahaan kecil akan memberikan return yang lebih tinggi dibandingkan perusahaan besar. Fenomena ini bertentangan dengan konsep pasar efisien, dimana tidak ada satupun informasi yang dapat digunakan pelaku pasar untuk mendapatkan return yang lebih tinggi (Tandelilin, 2010:219). 
Pengukuran kinerja portofolio saham dengan indeks Sharpe yang mengukur risiko dengan standar deviasi dikarenakan pembentukan portofolio saham berdasarkan ukuran perusahaan bukan berdasarkan karakteristik saham. Berdasarkan deskripsi teori dan hasil penelitian terdahulu yang telah diuraikan sebelumnya, maka hipotesis yang dapat diajukan dalam penelitian ini adalah:

H1: Terdapat perbedaan signifikan antara indeks Sharpe portofolio saham ukuran besar dibandingkan portofolio saham ukuran kecil

\section{METODE PENELITIAN}

Desain penelitian yang digunakan adalah desain penelitian komparatif yang membandingkan kinerja portofolio saham ukuran besar dengan kinerja portofolio saham ukuran kecil. Pengumpulan data dilakukan menggunakan metode observasi non partisipan dengan cara melakukan pengamatan, mencatat, serta melakukan akses ke beberapa situs seperti www.sahamok.com; www.yahoofinance.com; www.bi.go.id; serta www.idx.com untuk memperoleh data kapitalisasi pasar, harga saham penutupan, tingkat bunga Sertifikat Bank Indonesia (SBI), dan Indeks Kompas 100.

Populasi penelitian ini adalah semua saham yang terdaftar di Indeks Kompas 100 dari tahun 2012-2017 sebanyak 187 saham. Sampel yang digunakan dalam penelitian ini diambil secara purposive sampling, dengan kriteria (1) Saham perusahaan yang tercatat di Bursa Efek Indonesia dan konsisten terdaftar ke dalam Indeks Kompas 100 selama periode 2012-2017. Berdasarkan kriteria ini diperoleh 48 saham. (2) Saham diurutkan berdasarkan ukuran (kapitalisasi pasar) kemudian Memasukkan 20 saham teratas ke dalam portofolio saham ukuran besar dan 20 saham terbawah ke dalam portofolio saham ukuran kecil. (3) Mengeliminasi saham-saham yang tidak konsisten dalam portofolio saham ukuran besar maupun portofolio saham ukuan kecil selama periode penelitian. Saham yang konsisten masuk ke dalam portofolio saham ukuran besar dan portofolio saham ukuran kecil selama periode 2012-2017. Berdasarkan kriteria ini diperoleh 29 saham, dimana 17 saham masuk ke dalam portofolio saham ukuran besar dan 12 saham masuk ke dalam portofolio saham ukuran kecil.

Teknik analisis yang digunakan yaitu analisis deskriptif dan analisis statistik menggunakan uji beda dua rata-rata independen. Pengujian hipotesis penelitian dilakukan dengan membentuk portofolio saham ukuran besar dan portofolio saham ukuran kecil kemudian dihitung indeks Sharpe dari portofolio yang telah terbentuk. Hasil dari indeks Sharpe dari portofolio saham ukuran besar dan portofolio saham ukuran kecil kemudian dibandingkan menggunakan teknik analisis statistik uji beda dua rata-rata independen.

Langkah-langkah dalam pembentukan portofolio ini adalah: (1) Mengurutkan sahamsaham yang konsisten masuk ke dalam Indeks Kompas 100 selama periode 2012-2017 berdasarkan ukuran perusahaan (kapitalisasi pasar). (2) Memasukkan 20 saham teratas ke dalam portofolio saham ukuran besar dan 20 saham terbawah ke dalam portofolio saham ukuran kecil. (3) Mengeliminasi saham-saham yang tidak konsisten dalam portofolio saham ukuran besar maupun portofolio saham ukuran kecil selama periode penelitian sesuai dengan penelitian Banz (1981) dan Yanuar (2012). 
Indeks Sharpe portofolio dihitung dengan rumus:

$\widehat{S_{P}}=\frac{\overline{R_{P}}-\overline{R F}}{\widehat{\sigma_{T R}}}$

Keterangan:

$\widehat{S_{P}} \quad=$ IndeksSharpe portofolio saham

$\overline{R_{P}} \quad=$ Rata-rata return portofolio saham selama periode pengamatan

$\overrightarrow{R F} \quad=$ Rata-rata tingkat return bebas risiko selama periode pengamatan

$\widehat{\sigma_{T R}} \quad=$ Standar deviasi return portofolio saham selama periode pengamatan

Setelah diperoleh indeks Sharpe kemudian indeks sharpe portofolio saham ukuran besar dibandingkan dengan indeks sharpe portofolio saham ukuran kecil menggunakan uji beda dua rata-rata independen

\section{HASIL DAN PEMBAHASAN}

Indeks Sharpe portofolio saham ukuran besar dan portofolio saham ukuran kecil merupakan nilai indeks Sharpe dari masing-masing tahun observasi selama periode 20122017. Hasil perhitungan indeks Sharpe portofolio saham ukuran besar dan portofolio saham ukuran kecil dapat dilihat pada Tabel 1.

\section{Tabel 1. Tabel Indeks Sharpe Portofolio Saham Ukuran Besar dan Portofolio Saham} Ukuran Kecil Tahun 2012-2017

\begin{tabular}{ccc}
\hline $\begin{array}{c}\text { Tahun } \\
\text { Observasi }\end{array}$ & $\begin{array}{c}\text { Portofolio Saham } \\
\text { Ukuran Besar }\end{array}$ & $\begin{array}{c}\text { Portofolio Saham } \\
\text { Ukuran Kecil }\end{array}$ \\
\hline 2012 & 0,698 & 0,571 \\
2013 & $-0,328$ & $-0,459$ \\
2014 & 1,098 & 0,186 \\
2015 & $-1,259$ & $-1,607$ \\
2016 & 0,420 & 0,741 \\
2017 & 0,716 & $-0,779$ \\
\hline
\end{tabular}

Sumber: Data diolah, 2018

Perhitungan indeks Sharpe pada Tabel 1 menunjukkan bahwa portofolio saham ukuran kecil memberikan kinerja yang lebih baik dibandingkan portofolio saham ukuran besar hanya pada tahun 2016, sedangkan tahun-tahun lainnya menunjukkan portofolio saham ukuran kecil memberikan kinerja yang lebih rendah dibandingkan portofolio saham ukuran besar.

\section{Tabel 2 Tabel Rata-Rata Indeks Sharpe Portofolio Saham Ukuran Besar dan Portofolio} Saham Ukuran Kecil Tahun 2012-2017

\begin{tabular}{lcc}
\hline Kelompok Portofolio & Mean & Std. Deviation \\
\hline Portofolio Saham Ukuran Besar & .2242 & .86868 \\
Portofolio Saham Ukuran Kecil & -.2245 & .89524 \\
\hline Sumber: Data diolah, 2018 & &
\end{tabular}

Tabel 2 menunjukkan bahwa nilai rata-rata portofolio saham ukuran besar yaitu 0,2242 lebih tinggi dari nilai rata-rata portofolio saham ukuran kecil yaitu -0,2245 (0,2242>-0,2245). 
Nilai rata-rata tersebut menunjukkan bahwa kinerja portofolio saham ukuran besar lebih baik daripada kinerja portofolio saham ukuran kecil.

\section{Tabel 3. Tabel Uji Beda Indeks Sharpe Portofolio Saham Ukuran Besar dan Portofolio} Saham Ukuran Kecil Tahun 2012-2017

\begin{tabular}{llccc}
\hline & Sig. (2 - Tailed) & Mean-Difference & $\begin{array}{c}\text { Std. Error- } \\
\text { Difference }\end{array}$ \\
\hline $\begin{array}{l}\text { Indeks Sharpe } \\
\text { Portofolio }\end{array}$ & $\begin{array}{l}\text { Equal Variances } \\
\text { Assumed } \\
\text { Equal Variances } \\
\text { Not Assumed }\end{array}$ & .399 & .44867 & .50926 \\
& .399 & .44867 & .50926 \\
\hline Sumber: Data diolah, 2018 & &
\end{tabular}

Berdasarkan hasil uji beda, menunjukkan nilai sig sebesar 0,399 lebih besar dari taraf sig sebesar $0,05(0,399>0,05)$. Hasil ini berarti tidak ada perbedaan signifikan antara indeks Sharpe portofolio saham ukuran besar dengan portofolio saham ukuran kecil, sehingga hipotesis dalam penelitian ini ditolak.

Berdasarkan hasil uji beda pada indeks Sharpe portofolio saham ukuran besar dengan portofolio saham ukuran kecil, maka dapat dinyatakan bahwa anomali size effect tidak terjadi di Pasar Modal Indonesia khususnya pada saham-saham yang terdaftar di Indeks Kompas 100 selama periode 2012-2017. Hasil penelitian ini berlawanan dengan hasil penelitian Sobti (2018) di India, Boamah (2015) di Afrika Selatan, Iqram ul Haq and Kashif Rashid (2014) di Pakistan, Eraslan (2013) di Turki, Hwang et al. (2013) di Inggris, Simlai (2009) di Amerika Serikat, Nartea et al. (2009) di New Zeland, dan Rutledge et al. (2008) di China yang menunjukkan adanya anomali size effect pada pasar modal yang diteliti. Perbedaan ini diperkirakan disebabkan oleh karakteristik investor di Pasar Modal Indonesia yang berbeda dengan karakteristik investor di pasar modal negara lainnya (Yanuarta, 2012). Penelitian serupa di Indonesia yang juga menunjukkan tidak adanya anomali size effect yaitu Yanuarta (2012), Yani (2014), Mikhael dan Widanaputra (2018), serta Kurniawan dan Purbawangsa (2018), dimana hasil penelitiannya di Pasar Modal Indonesia juga menunjukkan tidak adanya anomali size effect di Pasar Modal Indonesia. Penelitian di pasar modal negara lain yang juga tidak menunjukkan adanya anomali size effect adalah penelitian yang dilakukan Alioui et al. (2015) di Amerika Serikat, Mazviona et al. (2014) di Zimbabwe, dan Razak et al. (2011) di Malaysia.

Berdasarkan nilai standar deviasi pada Tabel 2 dan 3 terdapat hal yang menarik, dimana nilai standar deviasi dari indeks Sharpe dari masing-masing portofolio menunjukkan bahwa portofolio saham ukuran kecil memiliki standar deviasi yang lebih tinggi dibandingkan portofolio saham ukuran besar. Standar deviasi indeks Sharpe portofolio saham ukuran kecil yaitu 0,895 lebih tinggi dari standar deviasi indeks Sharpe portofolio saham ukuran besar yaitu 0,869. Besarnya nilai standar deviasi menunjukkan bahwa portofolio saham ukuran kecil memiliki risiko yang lebih besar daripada portofolio saham ukuran besar. Standar deviasi menggambarkan proksi risiko berhubungan dengan ketidakpastian return yang diterima pada periode berikutnya oleh investor. Risiko yang terkandung dalam portofolio seharusnya sebanding dengan return yang diberikan portofolio tersebut. Penelitian ini menunjukkan risiko yang terdapat dalam portofolio tidak sebanding dengan return yang diperoleh investor. 
Berdasarkan efficient market hypoteis yang dikemukakan oleh Fama, efisiensi bentuk lemah berarti investor dapat memanfaatkan informasi masa lalu dalam mempertimbangkan strategi investasinya di masa sekarang, namun dalam penelitian ini menunjukkan bahwa informasi ukuran perusahaan tidak mampu membantu investor dalam memperoleh abnormal return.

Implikasi teoritis penelitian ini menunjukkan bahwa teori pasar efisien dalam bentuk lemah tidak terbukti melalui pengujian kinerja portofolio yang dikaitkan dengan karakteristik perusahaan yaitu ukuran perusahaan. Implikasi praktisnya bagi invertor adalah memberikan informasi bahwa ukuran perusahaan tidak berpegaruh terhadap kinerja portofolio saham.

Keterbatasan penelitian ini hanya mengunakan kapitalisasi pasar dalam mengukur ukuran perusahaan, pada penelitian berikutnya gunakan proksi lain untuk ukuran perusahaan seperti PER.

\section{SIMPULAN}

Berdasarkan kinerja indeks Sharpe, portofolio saham ukuran besar sebagian besar bernilai positif selama periode 2012-2017, sedangkan abnormal return dan indeks Sharpe portofolio saham ukuran kecil periode 2012-2017 tergolong buruk. Berdasarkan ukuran kinerja abnormal return maupun indeks Sharpe, portofolio saham ukuran kecil sebagian besar bernilai negatif selama periode 2012-2017. Kinerja portofolio saham ukuran besar lebih baik daripada kinerja portofolio saham ukuran kecil, yang oleh Indeks Sharpe lebih tinggi pada portofolio saham ukuran besar dibandingkan portofolio saham ukuran kecil. Hasil ini bertentangan dengan hipotesis anomali size effect, dimana seharusnya portofolio saham ukuran kecil memiliki kinerja yang lebih baik daripada portofolio saham ukuran besar. Uji signifikan menunjukkan tidak terdapat perbedaan yang signifikan antara kedua portofolio, hal ini berarti perbedaan nilai rata-rata tersebut cukup tipis sehingga tidak signifikan. Jadi anomali size effect tidak terjadi di Pasar Modal Indonesia khususnya pada saham-saham yang terdaftar di Indeks Kompas 100 periode 2012-2017.

Saran yang dapat diberikan kepada investor adalah ukuran perusahaan tidak berpengaruh terhadap kinerja portofolio sehingga sebaiknya investor tidak menggunakan ukuran perusahaan dalam pembentukan portofolio.

\section{REFERENSI}

Alioui, Sabrina, Bing Xiao, \& Anissa Chaibi. (2015). On The Impact of Firm Size on Risk and Return: Fresh Evidence from The American Stock Market Over The Recent Years, Journal of Applied Business Research, 31 (1), 29-36.

Ardiana, Agus. (2016). Investasi Saham. Hibah Buku Ajar Jurusan Akuntansi FEB Unud.

Balakrishnan \& Moinak Maiti. (2015). Performance of Micro Stocks in Indian Stock Market, Journal of Contemporary Research in Management, 10 (3), 45-50.

Banz, Rolf W. (1981). The Relationship Between Return and Market Value of Cammon Stocks. Journal of FinancialEconomics, 9 (1), 3-18

Boamah, Nicholas Addai. (2015). Robustness of the Carhart Four-Factor and the Fama-French Three-Factor Models on the South African Stock Market, Journal of Accounting and Finance, 14 (4), 413-430. 
Dewi, Kartika \& Luh Gede Sri Artini. (2014). Pengujian Efisiensi Pasar Bentuk Setengah Kuat, E-Jurnal Manajemen Unud, 3 (12), 3540-3557.

Dwipayana, Putra \& I Gusti Bagus Wiksuana. (2017). Pengujian Efisiensi Pasar di Bursa Efek Indonesia, E-Jurnal Manajemen Unud, 6 (4), 2105-2132.

Eraslan, Veysel. (2013). Fama and French Three-Factor Model: Evidence from Istanbul Stock Exchange, Business and Economics Research Journal, 4 (2), 11-22.

Haq, Ikram ul and Kashif Rashid (2014). Stock Market Efficiency and Size of the Firm: Empirical Evidence from Pakistan, Economics of Knowledge, 6 (1), 10-31.

Hartono, Jogiyanto. (2017). Teori Portofolio dan Analisis Investasi(Edisi Sebelas). Yogyakarta:BPFE

Hwang, Tienyu, Simon Gao, \& Heather Owen. (2013). Markowitz Efficiency and Size Effect: Evidence from the UK Stock Market, Journal of Quantitative Finance and Accounting, 43 (40), 721-750.

Jones, Charles P. (2014). Investments Principles and Concepts (Twelfth Edition).Singapore: John Wiley \& Sons Singapore Pte, Ltd.

Kurniawan, Suryo \& Anom Purbawangsa. (2018). Pengujian Anomali Pasar Size Effect dan The Day of Week Effect di Bursa Efek Indonesia. E-Jurnal Ekonomi dan Bisnis Universitas Udayana, 7 (9), 2147-2174.

Mazviona, Batsirai Winmore \& Davis Nyangara. (2014). Does Firm Size Affect Stock Returns? Evidence from the Zimbabwe Stock Exchange, International Journal of Business and Economic Development (IJBED), 2 (3), 13-17.

Mikhael, Yan Pleti \& Widanaputra. (2018). Pengujian Anomali Pasar Size Effect pada Bulan Januari di Pasar Modal Indonesia Tahun 2012-2015. E-Jurnal Akuntansi Universitas Udayana, 24 (1), 559-577

Nartea, Gilbert V, Bert D. Ward, \& Hadrian G. Djajadikerta. (2009). Size, BM, and Momentum Effects and the Robustness of the Fama-French Three-Factor Model Evidence from New Zealand,International Journal of Managerial Finance, 5 (2), 179-200.

Octavio, Danes Quirira\& Nuka Lantara. (2014). Market Overaction, Size Effect atau Liquidity Effect? Studi pada Bursa Efek Indonesia, Jurnal Manajemen Strategi Bisnis dan Kewirausahaan, 8 (1), 11-17.

Pandey, Asheesh \& Sanjay Sehgal. (2015). Explaining Size Effect for Indian Stock Market, Journal of Financial Studies, 23 (5), 45-68.

PT Kustodian Sentral Efek Indonesia. (2017). KSEI Terus Upayakan Kemudahaan Pembukaan Rekening Investasi. Diunduh dari Kustodian Sentral Efek Indonesiawebsite:http://www.ksei.co.id/files/uploads/press_ releases/press_file/idid/135 berita pers ksei_terus_upayakan kemudah_pembukaan_r ekening_investasi_20170816154208.pdf.

Razak, Abdul, Jaafar Pyeman, \& Wan Mansor Wan Mahmood. (2011). A Quest for SmallFirm Effect: Evidence from KLSE Second Board, Journal of Financial Economic, 9 (3), 28-39

Rutledge, Robert W, Zhaohui Zhang, \& Khondkar Karim. (2008). Is There a Size Effect in the Pricing of Stocks in the Chinese Stock Markets?: The Case of Bull Versus Bear Markets, Journal of Managerial Finance, 15 (2), 117-133.

Saputro, R. Narendra \& Ida Bagus Badjra. (2016). Kinerja Portofolio saham Berdasarkan Strategi Investasi Momentum Pada Industri Manufaktur, E-Jurnal Manajemen Unud, 5 (1), 623-649.

Sehgal, Sanjay \& Balakrishnan. (2013). Robustness of Fama-French Three Factor Model: Further Evidence for Indian Stock Market, Journal of Management, 17 (2), 119-127. 
Simlai, Pradosh. (2009). Stock Returns, Size, and Book-to-market Equity, Journal in Economics and Finance, 26 (3), 198-212.

Sobti, Neharika. (2018). Does Size, Value and Seasonal Effects Still Persist in Indian Equity Markets?, Journal of Financial Studies, 22 (1), 11-21.

Tandelilin, Eduardus. (2010). Portofolio dan Investasi(Edisi Pertama). Yogyakarta: Kanisius

Washer, Kenneth M, Srinivas Nippani, \& Robert R. Johnson. (2016). Santa Claus Rally and Firm Size, Journal of Managerial Finance, 42 (8), 817-829.

Yani, Aulia Rahma. (2014). January Effect dan Size Effect,Jurnal Manajemen Strategi Bisnis dan Kewirausahaan,4 (2), 13-30

Yanuarta, Ramael. (2012). Anomali Size Effect di Bursa Efek Indonesia. Jurnal Kajian Manajemen Bisnis Universitas Negeri Padang, 1 (1), 39-58. 